\title{
Anaplastic Carcinoma Cell
}

National Cancer Institute

\section{Source}

National Cancer Institute. Anaplastic Carcinoma Cell. NCI Thesaurus. Code C36848.

A malignant epithelial cell, usually of large size, characterized by the lack of differentiation. Anaplastic carcinoma cells have large hyperchromatic nuclei and display marked variation in nuclear size and shape, and high mitotic rate. Atypical mitotic figures are often present. 